\title{
ANALISIS SISTEM ANTREAN PADA LOKET PENDAFTARAN POLIKLINIK SPESIALIS DI RS BALIMED
}

\author{
Kadek Dita Sugiari $^{1 \S}$, I Wayan Sumarjaya ${ }^{2}$, Ketut Jayanegara ${ }^{3}$ \\ ${ }^{1}$ Program Studi Matematika, Fakultas MIPA - Universitas Udayana [Email: ditasugiari@gmail.com] \\ ${ }^{2}$ Program Studi Matematika, Fakultas MIPA - Universitas Udayana [Email: sumarjaya@unud.ac.id] \\ ${ }^{3}$ Program Studi Matematika, Fakultas MIPA - Universitas Udayana [Email: ktjayanegara@unud.ac.id] \\ ${ }^{\S}$ Corresponding Author
}

\begin{abstract}
Hospital is one of the service facilities that is not free from queue problem. One example of this hospital is Balimed Hospital. At certain times, especially in the morning, there is a lineup of patients at the Balimed Hospital's Specialist Polyclinic. In order to maximize service, it is necessary to analyze the queuing system by applying the queuing theory. This study focuses on queues at the Balimed Hospital's Specialist Polyclinic in Internal Disease. After conducting the research, it was found that the model used at the Specialist Polyclinic in Internal Disease is $(M / M / 1)$ : $(G D / \infty / \infty)$. With this model, the queuing system at Balimed Hospital's Specialist Polyclinic in Internal Disease is in steady state condition because $\rho<1$. The measures of performance for queuing system at Balimed Hospital's Specialist Polyclinic in Internal Disease is the average number of patients in queue $\left(L_{q}\right)$ is 0,1 patient or it can be said that there is almost no patient in queue because the value of $L_{q}$ is close to 0 , the average number of patients in system $\left(L_{s}\right)$ is 1 patient, the average waiting time for patients in queue $\left(W_{q}\right)$ is 1 minute, and the average time spent by patients start from queuing until being served $\left(W_{s}\right)$ is 2,5 minutes. The queuing system has been effective, it can be seen from the short waiting time for patients.
\end{abstract}

Keywords: Balimed Hospital's Spesialist Polyclinic in Internal Disease, queuing system, service

\section{PENDAHULUAN}

Antrean sering dijumpai pada beberapa fasilitas pelayanan umum yang diawali dengan kedatangan, menunggu untuk memperoleh pelayanan, hingga proses pelayanan selesai. Mengantre merupakan salah satu permasalahan yang menjadi bagian dari kehidupan setiap orang. Terlalu lama mengantre bisa menyebabkan konsumen beralih. Hal ini berarti lama waktu tunggu memiliki pengaruh pada kepuasan konsumen terhadap suatu fasilitas pelayanan. Oleh karena itu, suatu perusahaan berusaha mengurangi waktu tunggu untuk meningkatkan pelayanan kepada pelanggan. Hal ini dapat dilakukan dengan menambah fasilitas pelayanan, sehingga diharapkan masalah antrean bisa ditanggulangi. Namun bagi beberapa perusahaan, hal ini justru akan memunculkan masalah baru yaitu menambah pengeluaran. Dengan demikian perlu dilakukan analisis sistem antrean pada suatu fasilitas pelayanan.
Menurut Heizer dan Render (2011), antrean adalah orang atau barang dalam sebuah barisan yang sedang menunggu untuk dilayani. Sedangkan menurut Dimyati dan Dimyati (2009), teori antrean adalah teori yang menyangkut studi matematis dari antreanantrean atau baris-baris penungguan. Teori antrean membantu memberikan gambaran terkait hal-hal yang diperlukan oleh penyedia fasilitas pelayanan dalam membuat keputusan terkait baris-baris penungguan, seperti rata-rata waktu tunggu pelanggan (Bhat, 2008).

Sedangkan sistem antrean merupakan suatu sistem yang terdiri dari pelanggan, fasilitas pelayanan, serta aturan mengenai kedatangan pelanggan dan pemecahan masalah pelayanan antrean (Subagyo, dkk., 2000). Untuk mengoptimalkan pelayanan, dapat diterapkan teori antrean dengan perhitungan secara sistematis sehingga diperoleh suatu kesimpulan 
terkait masalah yang terjadi pada suatu sistem antrean.

Salah satu tempat yang tidak luput dari masalah antrean adalah rumah sakit. Menjamurnya penawaran jasa kesehatan menimbulkan persaingan untuk meningkatkan kepuasan pasien, maka dari itu tiap rumah sakit dituntut untuk terus meningkatkan sistem pelayanan yang ada. Rumah Sakit Balimed merupakan rumah sakit umum swasta yang menjadi salah satu penyedia layanan kesehatan terbaik di Bali. Meskipun RS Balimed merupakan rumah sakit swasta namun rumah sakit ini tetap melayani pasien BPJS. Penelitian ini terfokus pada Poliklinik Spesialis Penyakit Dalam RS Balimed yang selalu ramai setiap harinya, khususnya pada pagi hari. Berdasarkan hal tersebut, penulis tertarik melakukan penelitian yang bertujuan untuk mengetahui model antrean serta ukuran kinerja sistem antrean pada Poliklinik Spesialis Penyakit Dalam RS Balimed.

\section{METODE PENELITIAN}

Jenis data dalam penelitian ini adalah data primer berupa data waktu kedatangan dan waktu pelayanan pasien di Poliklinik Spesialis Penyakit Dalam RS Balimed yang beralamat di Jalan Mahendradatta No. 57X, Denpasar. Data pada penelitian ini diperoleh melalui pengamatan langsung di Poliklinik Spesialis Penyakit Dalam RS Balimed, wawancara dengan Kepala Unit Admisi RS Balimed, serta penelusuran literatur yang berkaitan dengan teori antrean. Pengamatan dilakukan pada hari Senin-Sabtu saat jam-jam sibuk, yaitu pukul 08.00-11.00 WITA.

Dalam penelitian ini teknik pengumpulan data dilakukan dengan tiga cara yaitu:

a. Metode Observasi

Peneliti melakukan pengamatan langsung dan pengambilan data di Poliklinik Spesialis Penyakit Dalam RS Balimed Denpasar. Permasalahan yang diteliti yaitu mengenai sistem antrean pada Poliklinik Spesialis Penyakit Dalam RS Balimed.

b. Metode Wawancara

Peneliti melakukan wawancara dengan Kepala Unit Admisi RS Balimed untuk memperoleh gambaran mengenai sistem antrean yang diterapkan serta permasalahan yang terjadi. c. Metode Literatur

Peneliti melakukan penelusuran literatur yang berkaitan dengan materi yang digunakan untuk mendukung penelitian ini.

Teknik analisis data dilakukan untuk mencapai tujuan penelitian dengan langkahlangkah berikut.

1. Menginput data waktu kedatangan pasien dan waktu pelayanan pasien.

2. Melakukan uji Kolmogorov-Smirnov untuk menguji kecocokan distribusi pola kedatangan dan pola pelayanan pasien.

Hipotesis distribusi kedatangan pasien adalah:

$H_{0}$ : Kedatangan pasien di Poliklinik Spesialis Penyakit Dalam RS Balimed berdistribusi Poisson.

$H_{1}$ : Kedatangan pasien di Poliklinik Spesialis Penyakit Dalam RS Balimed tidak berdistribusi Poisson.

Kedatangan pasien diasumsikan berdistribusi umum (general) jika tidak berdistribusi Poisson.

Hipotesis mengenai waktu pelayanan adalah:

$H_{0}$ : Waktu pelayanan pasien di Poliklinik Spesialis Penyakit Dalam RS Balimed berdistribusi eksponensial.

$H_{1}$ : Waktu pelayanan pasien di Poliklinik Spesialis Penyakit Dalam RS Balimed tidak berdistribusi eksponensial.

Waktu pelayanan pasien diasumsikan berdistribusi umum (general) jika tidak berdistribusi eksponensial.

Hasil keputusan $H_{0}$ dilakukan dengan membandingkan nilai $D_{\text {hitung }}$ dengan nilai $D_{\text {tabel }}$. Jika nilai $D_{\text {hitung }}<D_{\text {tabel }}$ maka disimpulkan bahwa $H_{0}$ diterima.

3. Menentukan model antrean berdasarkan notasi Kendall yang dinotasikan dengan $(a / b / c):(d / e / f)$.

4. Menghitung ukuran kinerja sistem antrean seperti $L_{q}, L_{s}, W_{q}$, dan $W_{s}$.

5. Melakukan pemeriksaan steady state. Data yang diperoleh dikatakan dalam kondisi tetap (steady state) apabila $\rho=\frac{\lambda}{c \mu}<1$.

Sebaliknya jika $\rho \geq 1$ maka rata-rata laju kedatangan pasien $(\lambda)$ lebih dari rata-rata laju pelayanan $(\mu)$, sehingga kondisi steady state tidak terpenuhi.

6. Menginterpretasikan hasil analisis data sehingga dapat digunakan sebagai bahan 
pertimbangan dalam pengambilan keputusan mengenai sistem antrean pada Poliklinik Spesialis Penyakit Dalam RS Balimed.

\section{HASIL DAN PEMBAHASAN}

Hasil yang diperoleh dari analisis data adalah kedatangan pasien pada Poliklinik Spesialis Penyakit Dalam berdistribusi Poisson (M), waktu pelayanan pasien berdistribusi eksponensial (M), jumlah server yaitu 1 dokter dengan aturan pasien yang pertama datang akan dilayani terlebih dahulu, kapasitas sistem dan sumber pemanggilan yang tidak terbatas. Hal ini berarti model antrean pada Poliklinik Spesialis Penyakit Dalam RS Balimed adalah $(M / M / 1):(G D / \infty / \infty)$.

Setelah diperoleh model antrean, langkah selanjutnya adalah penentuan ukuran kinerja sistem antrean. Ukuran kinerja sistem antrean dengan model $(M / M / 1):(G D / \infty / \infty)$ dapat dihitung dengan menggunakan rumus berikut.

1. Rata-rata Jumlah Pasien dalam Antrean $\left(L_{q}\right)$

$L_{q}=\frac{\lambda^{2}}{\mu(\mu-\lambda)}=0,1$ pasien.

2. Rata-rata Jumlah Pasien dalam Sistem $\left(L_{s}\right)$ $L_{s}=\frac{\lambda}{\mu-\lambda}=0,38$ pasien

3. Rata-rata Waktu Tunggu Pasien dalam Antrean $\left(W_{q}\right)$

$W_{q}=\frac{\lambda}{\mu(\mu-\lambda)}=1$ menit.

4. Rata-rata Waktu Tunggu Pasien dalam Sistem $\left(W_{S}\right)$

$W_{s}=\frac{1}{\mu-\lambda}=2,5$ menit.

Perhitungan tersebut menunjukkan bahwa rata-rata jumlah pasien yang menunggu untuk dilayani adalah 0,1 pasien atau dapat dikatakan hampir tidak ada pasien yang mengantre karena nilai $L_{q}$ mendekati 0 , rata-rata jumlah pasien dalam sistem (jumlah pasien yang sedang mengantre dan sedang dilayani) adalah 1 pasien, rata-rata waktu tunggu pasien untuk memperoleh pelayanan yaitu selama 1 menit, dan rata-rata waktu yang dihabiskan pasien mulai dari menunggu hingga selesai dilayani yaitu selama 2,5 menit.

Selanjutnya dilakukan pengecekan steady state terhadap sistem antrean dengan perhitungan sebagai berikut:

$$
\rho=\frac{\lambda}{c \mu}=0,27
$$

Nilai $\rho<1$ menunjukkan bahwa sistem antrean pada Poliklinik Spesialis Penyakit Dalam RS Balimed sudah berada dalam keadaan steady state dengan laju kedatangan pasien lebih kecil daripada laju pelayanan pasien.

\section{KESIMPULAN}

\subsection{Kesimpulan}

Memerhatikan hasil dan pembahasan disimpulkan bahwa kedatangan pasien berdistribusi Poisson (M), waktu pelayanan pasien berdistribusi eksponensial (M), jumlah server yaitu 1 dokter, kapasitas sistem dan sumber pemanggilan yang tidak terbatas. Hal ini menunjukkan bahwa model antrean pada Poliklinik Spesialis Penyakit Dalam di RS Balimed adalah $(M / M / 1):(G D / \infty / \infty)$.

Ukuran kinerja sistem antrean pada Poliklinik Spesialis Penyakit Dalam di RS Balimed adalah rata-rata jumlah pasien dalam antrean (pasien yang menunggu untuk dilayani) adalah 0,1 pasien atau dapat dikatakan hampir tidak ada pasien yang mengantre, sedangkan rata-rata jumlah pasien dalam sistem (jumlah pasien yang seang mengantre dan sedang dilayani) adalah 1 pasien. Rata-rata waktu tunggu pasien untuk memperoleh pelayanan yaitu selama 1 menit, sedangkan rata-rata waktu yang dihabiskan pasien mulai dari mengantre hingga selesai dilayani yaitu selama 2,5 menit.

\subsection{Saran}

Berdasarkan hasil penelitian yang diperoleh, sistem antrean pada Poliklinik Spesialis Penyakit Dalam di RS Balimed sudah baik, dapat dilihat dari rata-rata waktu tunggu pasien yang relatif singkat. Oleh karena itu tidak diperlukan penambahan server (dokter) pada pagi hari untuk Poliklinik Spesialis Penyakit Dalam RS Balimed.

Sistem antrean pada penelitian ini hanya terbatas dari pasien datang mengambil nomor antrean hingga pasien keluar dari ruang periksa, untuk penelitian selanjutnya mengenai sistem antrean di poliklinik disarankan untuk melakukan pengamatan hingga pasien mengantre di loket farmasi untuk proses pengambilan obat. 


\section{DAFTAR PUSTAKA}

Bhat, U. N. (2008). An Introduction to Queuing Theory, Modelling, and Analysis in Applications. Dallas: Birkhauster Boston.

Dimyati, A., \& Dimyati, T. T. (2009). Operations Research "Model-model
Pengambilan Keputusan". Bandung: PT. Sinar Baru Algesindo.

Heizer, J., \& Reinder, B. (2011). Operations Management 10th Edition. New Jersey: Prentice Hall, Inc.

Subagyo, P., Asri, M., \& Handoko, T. H. (2000). Dasar-dasar Operations Research. Yogyakarta: BPFE. 